\title{
OBSERVATIONS ON FOETAL HAEMOGLOBIN
}

\author{
BY \\ C. GARDIKAS, D. G. SCOTT and JOHN F. WILKINSON \\ From the Department of Haematology, Manchester Royal Infirmary and Manchester University.
}

(RECEIVED FOR PUBLICATION AUgUST 26, 1952)

Foetal haemoglobin exhibits a much greater resistance towards alkaline denaturation than does adult haemoglobin, thus constituting an important distinction between the two types of haemoglobin. The phenomenon was first described by Körber (1866), observed again by Krüger (1887-88), and subsequently studied in more detail by Bischoff (1926), Haurowitz (1929, 1930), and Brinkman, Wildschut and Wittermans (1934). The latter developed a photoelectric method that enabled them to work with mixtures of pigments having different degrees of resistance to alkaline denaturation.

Further study has demonstrated that the two types of haemoglobin differ also in many other properties (Table 1). However, the most pronounced difference so far described is to be noted in the speeds of denaturation by alkali, but the mechanism is not yet understood. No report could be found in the literature describing the behaviour of the two types of haemoglobin under the influence of other denaturing agents.

Among such agents, urea and salicylates are known to bring about denaturation of haemoglobin, and at the same time maintain the thus denatured protein in solution. Urea in concentrated solution causes denaturation of haemoglobin and, in addition, horse (Astbury and Lomax, 1935) or ox (Huang and $\mathrm{Wu}, 1930)$ haemoglobin molecules are dissociated into half molecules as determined by osmotic pressure measurements. The effect of varying concentrations of urea and related amides on horse haemoglobin has been studied extensively by Steinhardt (1938) who found, when working with horse methaemoglobin formed by the action of potassium ferricyanide, that within 20 hours at room temperature the characteristic absorption spectral band in the red $(630 \mu)$ fades and is replaced by a diffuse band in the green (at approximately 534:L). It was concluded that the latter band was not due to ferrohaemochromogen since, on treatment with sodium hydrosulphite, the typical absorption spectrum of ferrohaemochromogen did not appear.

The denaturing effect of sodium salicylate on bovine methaemoglobin was examined in detail by Anson and Mirsky (1934). They measured the increase in the spectral absorption in the green and found that when salicylate was added to native methaemoglobin the absorption in the green at first increased rapidly, then remained constant and finally increased again very slowly. The concentration of salicylate in their experiments varied from $0.05 \mathrm{M}$ to $0.5 \mathrm{M}$ and they observed that greater proportions of denatured protein were produced and with increasing concentration of salicylate the speed of reaction was also increased. Using $0.5 \mathrm{~m}$ salicylate solutions denaturation was complete in $\mathbf{3 0}$ minutes.

In the present study we have subjected foetal and adult methaemoglobin to the denaturing action of urea and salicylate and studied the behaviour of the two pigments. These two denaturing agents were chosen since, in the concentrations used, they possess the property of keeping the denatured protein in solution, thus facilitating spectroscopic studies and photometric determinations.

\section{Experimental}

Material. Venous blood freshly withdrawn from healthy adults and cord blood were used as sources of adult and foetal haemoglobin respectively: cord blood contained foetal haemoglobin in concentrations varying from $75 \%$ to $85 \%$ of the total haemoglobin as determined by the technique of Ponder and Levine (1949).

Pure haemoglobin solutions were prepared from the erythrocytes after repeated washings with $0.9^{\circ}{ }_{0} \mathrm{w}$. $\mathrm{NaCl}$; dilution with 1.0 to $1.5 \mathrm{vol}$. of distilled water. thorough mixing with $0.4 \mathrm{vol}$. toluol, centrifugation, and siphoning off the clear haemoglobin solution which was finally filtered.

Methaemoglobin was prepared from the above haemoglobin solutions by the use of potassium ferricyanide according to Anson and Mirsky (1931). The reaction is stoichiometric and $1.1 \mathrm{~mol}$. of the oxidizing agent was added per atom of Fe using $1^{\circ} \mathrm{w} v$ solution of $\mathrm{K}_{3} \mathrm{Fe}(\mathrm{CN})_{6}$.

An $8.8 \mathrm{M}$ urea solution and a $1.0 \mathrm{M}$ sodium salicylate solution (both 'analar') were prepared, the latter being filtered and stored in the cold as suggested by Anson and Mirsky (1934). 
TABLE 1

SUMMARY OF DIFFERENCES BETWEEN FOETAL AND ADULT HAEMOGLOBINS

\begin{tabular}{|c|c|c|}
\hline Phenomenon & Distinctive Property & Reference \\
\hline Alkaline denaturation & .. Foetal haemoglobin more resistant than adult & $\begin{array}{l}\text { Körbet }(1866) \\
\text { Krüger }(1887) \\
\text { Bischoff }(1926) \\
\text { Haurowitz }(1929-30) \\
\text { Brinkman et al. (1934) }\end{array}$ \\
\hline $\mathrm{O}_{2}$ dissociation curve & $\begin{array}{l}\text { Foetal haemogjobin inside the erythrocyte has a higher oxygen } \\
\text { affinity and smaller value of 'n' in the Hill equation than adult haemo- } \\
\text { globin. }\end{array}$ & $\begin{array}{l}\text { Haurowitz (1935) } \\
\text { McCarthy and Popjak (1943) }\end{array}$ \\
\hline Solubility behaviour & $\begin{array}{l}\text { Definite difference in the solubility curves between human adult and } \\
\text { foetal haemoglobin } C O \text {, haemogbobin } O_{2} \text { and methaemoglobin. In } \\
\text { strong phosphate buffer foetal haemoglobin is more than six times as } \\
\text { soluble as adult haemoglobin. }\end{array}$ & $\begin{array}{l}\text { Jope and O'Brien (1949) } \\
\text { Wyman, Rafferty and Ingalls (1944) }\end{array}$ \\
\hline Crystallographic data & . Different characteristics in crystalline forms. & Jope and O'Brien (1949) \\
\hline Spectroscopic differences & $\begin{array}{l}\text {. In human foetal haemoglobin the fine 'tryptophane absorption band' } \\
\text { appears at } 289 \cdot 8 \cdot \mu \text { and in adult haemogbobin at } 291 \cdot 0.2 \text {. }\end{array}$ & Jope (1949) \\
\hline Amino-acid composition & $\begin{array}{l}\text { Human foetal haemoglobin contains } 2.6 \text { terminal valyl residues per } \\
\text { molecule compared with } 5 \text { in human adult haemoglobin. Bovine } \\
\text { adult haemGglobin contains more histidine than foetal haemoglobin. }\end{array}$ & $\begin{array}{l}\text { Porter and Sanger (1948) } \\
\text { Vickery (1942) }\end{array}$ \\
\hline Peroxidative effect & $\begin{array}{l}\text { Human foetal haemoglobin exhibits greater peroxidative activity than } \\
\text { adult haemoglobin. }\end{array}$ & Betke (1950) \\
\hline
\end{tabular}

Methods. Before its conversion to methaemoglobin the haemoglobin concentration was determined in an E.E.L. photoelectric colorimeter. The changes in the absorption during the experiment following the addition of the denaturing agent were determined using a 'unicam' diffraction grating spectrophotometer, and a Hartridge reversion spectroscope was employed for the spectroscopic observations.

Urea. Steinhardt's experimental conditions were applied. All solutions contained $0 \cdot 14 \mathrm{~g}$. methaemoglobin per $100 \mathrm{ml}$. and $0.1 \mathrm{M} \mathrm{KCl}$. The concentration of urea was $4.4 \mathrm{M}$ while the control solutions contained an equal volume of distilled water. The final volume of each solution was $10 \mathrm{ml}$. The optical density was measured at $630 \mu$ and $540 \mu$, taking readings every two hours for 24 hours.

REsults. The results obtained expressed as the mean of several experiments are summarized in Table 2 . It shows that the rate of denaturation of foetal methaemoglobin was quicker than that of adult methaemoglobin. Each individual experiment followed a very similar pattern and in no instance was the reading with the solution of foetal methaemoglobin at 540 lower than with the adult. At eight hours the denaturation of foetal methaemoglobin reached a stage which adult methaemoglobin attained only after 24 hours. The contrast in colour between the two solutions was apparent even to the naked eye.

Addition of sodium hydrosulphite produced the typical ferrohaemochromogen spectrum in both foetal and adult methaemoglobin solutions contrary to Steinhardt's observations. There was, however, a marked time difference, typical ferrohaemochromogen appearing at eight hours in the foetal methaemoglobin solution and at 24 hours in the adult methaemoglobin solution.

Salicylate. Anson and Mirsky's (1934) experimental conditions were applied. All solutions contained $0.1 \mathrm{~g}$. methaemoglobin per $100 \mathrm{ml}$. in $0.1 \mathrm{M}$ phosphate buffer, pH 6.8. Varying volumes of $1 \cdot 0 \mathrm{~m}$ sodium salicylate solution were added to obtain solutions containing $0 \cdot 0$, $0.2,0.4,0.5 \mathrm{M}$ salicylate. The final volume of each solution was $10 \mathrm{ml}$. Readings were obtained at $540 \mathrm{u}$ before and at $0.5,3,5,10,15,30,60$ and 120 minutes after the addition of salicylate.

REsulTs. Table 3 summarizes the results obtained and presents the mean of several experiments. This shows in contrast that the speed of denaturation of foetal methaemoglobin by salicylate was slower than that of the adult pigment in all concentrations. Each individual experiment led to the same conclusion and in no instance were the results conflicting. For the fuller appreciation of this fact from the table it must be noted that a difference of, say, 0.03 in the optical density represents over $10 \%$ of the total denaturation.

When sodium hyposulphite was added at 60 minutes, the typical ferrohaemochromogen spectrum was obtained in all solutions with salicylate.

\section{Discussion}

The above experiments show that foetal and adult haemoglobins, besides differing in stability to alkaline denaturation as already known, differ also in their resistances to denaturation by urea or sodium salicylate. The fact that the two types of blood pigment behave differently according to the denaturing agent, viz. higher resistance of foetal haemoglobin to denaturation by alkali or salicylate and lower resistance towards urea, can be understood in the light of the modern concept that denaturation is not a single phenomenon; that there 
TABLE 2

RATE OF DENATURATION OF ADULT AND FOETAL METHAEMOGLOBIN BY 4.4 M UREA AS DETERMINED BY THE INCREASE IN SPECTRAL ABSORPTION AT 540,2*

\begin{tabular}{|c|c|c|c|c|c|c|c|c|}
\hline \multirow{3}{*}{$\underset{\text { (minutes) }}{\text { Time }}$} & \multicolumn{4}{|c|}{ Adult Methaemoglobin } & \multicolumn{4}{|c|}{ Foetal Methaemoglobin } \\
\hline & \multicolumn{2}{|c|}{$\begin{array}{l}\text { Solution 1 } \\
\text { (with Urea) }\end{array}$} & \multicolumn{2}{|c|}{$\begin{array}{l}\text { Solution } 2 \\
\text { (Control) }\end{array}$} & \multicolumn{2}{|c|}{$\begin{array}{c}\text { Solution } 3 \\
\text { (with Urea) }\end{array}$} & \multicolumn{2}{|c|}{$\begin{array}{l}\text { Solution } 4 \\
\text { (Control) }\end{array}$} \\
\hline & $630 \mu$ & $540 \mu$ & $630 p$ & 5402 & $630 i 2$ & $540: 2$ & $630 \mu$ & $540 \mu$ \\
\hline $\begin{array}{r}0 \\
2 \\
4 \\
6 \\
8 \\
12 \\
14 \\
16 \\
18 \\
20 \\
24\end{array}$ & $\begin{array}{l}0 \cdot 54 \\
0 \cdot 53 \\
0 \cdot 51 \\
0 \cdot 50 \\
0 \cdot 50 \\
0 \cdot 49 \\
0 \cdot 49 \\
0 \cdot 50 \\
0 \cdot 48 \\
0 \cdot 44 \\
0 \cdot 42\end{array}$ & $\begin{array}{l}0.82 \\
0.86 \\
0.89 \\
0.90 \\
0.91 \\
0.92 \\
0.92 \\
0.94 \\
0.95 \\
0.98 \\
1.00\end{array}$ & $\begin{array}{l}0.49 \\
0.49 \\
0.49 \\
0.49 \\
0.51 \\
0.49 \\
0.49 \\
0.48 \\
0.48 \\
0.49 \\
0.48\end{array}$ & $\begin{array}{l}0.75 \\
0.765 \\
0.765 \\
0.76 \\
0.765 \\
0.76 \\
0.76 \\
0.76 \\
0.765 \\
0.765 \\
0.765\end{array}$ & $\begin{array}{l}0 \cdot 54 \\
0 \cdot 50 \\
0 \cdot 45 \\
0 \cdot 43 \\
0 \cdot 42 \\
0 \cdot 40 \\
0 \cdot 39 \\
0 \cdot 37 \\
0 \cdot 37 \\
0 \cdot 32 \\
0 \cdot 30\end{array}$ & $\begin{array}{l}0.84 \\
0.93 \\
0.98 \\
0.99 \\
1.00 \\
1.04 \\
1.05 \\
1.06 \\
1.07 \\
1.07 \\
1.09\end{array}$ & $\begin{array}{l}0.49 \\
0.50 \\
0.50 \\
0.50 \\
0 \cdot 51 \\
0.50 \\
0.49 \\
0.48 \\
0.50 \\
0.49 \\
0.48\end{array}$ & $\begin{array}{l}0 \cdot 74 \\
0 \cdot 745 \\
0 \cdot 745 \\
0 \cdot 755 \\
0 \cdot 76 \\
0 \cdot 76 \\
0 \cdot 75 \\
0 \cdot 76 \\
0 \cdot 77 \\
0 \cdot 75 \\
0 \cdot 75\end{array}$ \\
\hline
\end{tabular}

All solutions contained $0 \cdot 14 \mathrm{~g}$ methaemogbin per $100 \mathrm{ml}$. and $0 \cdot 1 \mathrm{M} \mathrm{KCl}$. Final volume of each solution $=10 \mathrm{ml}$.

- Readings express optical density and present the mean of several experiments.

are various kinds of denaturation; and that in each one of them the changes may involve various groups of the protein molecule.

The differences between the two types of haemoglobin described in the present paper in addition to those already described (Table 1) leave little doubt that there are definite ontogenetic variations of haemoglobin. Since the prosthetic haemin is identical in various haemoglobins the distinction between the two types must be attributed to the protein moieties. It is now accepted that the globin components of foetal and adult haemoglobin are different. In favour of this view further evidence has recently been brought forward by Betke (1950), who found that while haemin prepared from adult and foetal haemoglobin had similar peroxidative activity, foetal haemoprotein exhibited higher peroxidative activity than adult.

It would appear reasonable to subscribe to Drabkin's (1951) hypothesis that a structurally identical haemin combines with the particular and suitable protein available at the site of chromoprotein fabrication; thus 'liver' globin may be held responsible for the properties of foetal haemoglobin, and 'red bone marrow' globin for those of adult haemoglobin. However, this latter observation requires further experimental study.

\section{Summary}

A definite contrast in the speed of denaturation between foetal and adult haemoglobins was observed when urea and sodium salicylate were the denaturing agents.

In $4.4 \mathrm{M}$ urea solution foetal methaemoglobin denatured more quickly than adult methaemoglobin.

In solutions of sodium salicylate $(0.2$ to $0.5 \mathrm{M})$ foetal methaemoglobin was more resistant than adult methaemoglobin to denaturation.

The problem of differences of the two types of blood pigment is considered.

TABLE 3

RATE OF DENATURATION OF ADULT AND FOETAL METHAEMOGLOBIN BY SALICYLATE AS DETERMINED BY THE INCREASE IN SPECTRAL ABSORPTION AT $540 \mu^{*}$.

\begin{tabular}{|c|c|c|c|c|c|c|c|c|}
\hline \multirow{3}{*}{$\underset{\text { (minutes) }}{\text { Time }}$} & \multirow{2}{*}{\multicolumn{2}{|c|}{ Control }} & & & \multicolumn{2}{|c|}{ Salicylate Concentration } & & \\
\hline & & & & & & & \multicolumn{2}{|c|}{$0.5 \mathrm{M}$} \\
\hline & A. & F. & A. & F. & A. & F. & A. & F. \\
\hline $\begin{array}{c}0 \cdot 5 \\
3 \\
5 \\
10 \\
15 \\
30 \\
60 \\
120\end{array}$ & $\begin{array}{l}0.41 \\
0.41 \\
0.415 \\
0.415 \\
0.415\end{array}$ & $\begin{array}{l}0.41 \\
0.41 \\
0.415 \\
0.415 \\
0.415\end{array}$ & $\begin{array}{l}0 \cdot 50 \\
0 \cdot 535 \\
0 \cdot 55 \\
0 \cdot 56 \\
0 \cdot 56 \\
0 \cdot 56 \\
0 \cdot 57 \\
0 \cdot 575\end{array}$ & $\begin{array}{l}0 \cdot 47 \\
0 \cdot 495 \\
0 \cdot 50 \\
0 \cdot 51 \\
0 \cdot 52 \\
0 \cdot 53 \\
0 \cdot 54 \\
0 \cdot 56\end{array}$ & $\begin{array}{l}0.61 \\
0.66 \\
0.66 \\
0.66 \\
0.66 \\
0.67\end{array}$ & $\begin{array}{l}0.59 \\
0.62 \\
0.625 \\
0.625 \\
0.63 \\
0.635\end{array}$ & $\begin{array}{l}0.66 \\
0.665 \\
0.665 \\
0.665 \\
0.67 \\
0.68\end{array}$ & $\begin{array}{l}0.62 \\
0.63 \\
0.63 \\
0.63 \\
0.63 \\
0.64\end{array}$ \\
\hline
\end{tabular}

A.=Adult. $\quad \mathbf{F}$. $=$ Foetal.

- Readings express optical density. 
REFERENCES

Anson, M. L. and Mirsky, A. E. (1931). J. phys. Chem., 35, 185. Petke K (1934). J. gen. Physid., 17, 399.

Bischoff, H. (1926). Z. ges. exp. Med, 48, 472

Brinkman, R., Wildschut, A. and Wittermans, A. (1934). J. Physiol. man, $\mathbf{R} 77$.

Drabkin, D. L. (1951). Physiol. Rev., 31, 345.

Haurowitz, F. (1929). Z. physiol. Chem., 183. 78.

(1930). Ibid., 186, 141.

Huang, T. C. and Wu, H. (1930). Chinese J. Physiol., 4, 221.

Jope, E. M. (1949). Haemoglobin, ed. Roughton, F. J. W. and Kendrew, J. C., p. 205 . London.
Jope, E. M. and O'Brien, J. R. P. (1949). Haemoglobin, p. 269. London.

Körber, E. (1866). Über Differengen des Blutfarbstoffs. Inaug. Dissertation. Dorpat.

Krüzer, F. (1887-88). Z. Biol., 24, 318.

McCarthy, E. F. and Popják, G. (1943). Biochem. J., 37. xviii.

Ponder, E. and Levine, P. (1949). Blood, 4. 1264.

Porter, R. R. and Sanger, F. (1948). Biochem. J., 42, 287.

Steinhardt, J. (1938). J. biol. Chem., 123, 543.

Vickery, H. B. (1942). J. biol. Chem., 144, 719. Quoted in Wyman, J., Jr. (1948). Advanc. Protein Chem., 4. 407.

Wyman, J., Jr., Rafferty, J. A. and Ingalk, E. N. (1944). J. biol. Chem., 153, 275. 